\title{
The Power of Directive Speech Acts in EFL Classroom Interaction
}

\author{
Sulistyani \\ Universitas Nusantara PGRI Kediri \\ Kediri, Indonesia \\ sulissulistyani@rocketmail.com
}

\begin{abstract}
This paper is written to reveal the performance of directive speech acts by an English teacher in SMAN 1 Kediri, Indonesia. This speech act type is worth analyzing as this speech act frequently occurs in classroom interaction. Three points that become the focus of analysis are the type, function, and the strategy use in issuing directives. Using observation and note taking, this qualitative study suggests that directive speech act takes the dominant role in classroom interaction. It is performed in three types namely, question, command, and suggestion with various structures categorized under interrogative, imperative, and declarative. The pedagogical functions represented by the teacher's directives are as asking for confirmation, asking question, elicitation, checking knowledge, checking comprehension, asking for clarification, asking for repetition, and checking learning, ordering the students to do something, calling attention, wishing something to happen, nominating the students, commanding, instructing, grouping, guiding, stimulating, and correcting the students' error and lastly, suggestion. The directive performance by the teacher is considered polite and appropriate even though imperative production exists. The reason is because of the relative status in which the teacher as a superior has the right or authority in using imperative. Other indicators of being polite is the use of politeness marker 'please', the word 'try', and also gentle intonation. The use of interrogative and declarative, being indirect, also increase politeness. In short, the EFL classroom interaction in SMAN 1 Kediri reflects Searle's and Holmes' view of directive speech act.
\end{abstract}

Keywords: directive speech acts; classroom interaction

\section{INTRODUCTION}

This paper focuses on describing the realization of directive speech acts in classroom interaction as one aspect of interpersonal discourse management. This speech act type is worth analyzing as this speech act frequently occurs in classroom interaction. There are other reasons that make an analysis of directive speech act interesting: they are typical face-threatening acts and should therefore allow observation of 'politeness' in the conventional sense specifically the workings of discourse modification and mitigation strategies. And secondly, this kind of speech acts occurs frequently in classroom interaction.
Based on Searle's taxonomy of speech acts, directives are speech acts which impose some kind of action on the hearer. Commands, orders, advice, requests, warnings etc. are examples of such speech acts [1] According to reference [2] all these utterances represent "attempts on the part of the speaker to get the hearer to perform some kind of action or cessation of action." Establishment of a terminological distinction between the different kinds of directives that goes beyond their general lexical meaning is not an easy thing. On the one hand, [3] explain that what makes a request a request and a command a command are the general conditions of interaction while in term of directness for instance is then about a choice. However, in reality, the conditions and realizations are impossible to tease apart. This may explain why, in the pragmatics literature, the term request is frequently used as an umbrella term and quasi-synonym of directive [2].

Having function as interpersonal discourse management, directive seems to be dominant in EFL classrooms. [4] analysis of elementary classroom speech acts classification shows that the teacher dominates declaratives, expressive, and directives with directives being the most frequently expressed, while the students dominate representatives and commissives with representatives being more frequent. Another study which looks specifically at teachers' directives in foreign language classrooms is reported by [5]. The authors examine directives as indices of student-teacher status relationships, finding significant differences between Japanese (both as a foreign and as a native language) and English as a medium of instruction. Teacher directives in those elementary classrooms where Japanese was the medium of instruction were significantly more direct than in the English medium ones. They conclude that the high level of directness reflects the status differential between students and teachers but also characterizes the relationship between teacher and young students as close and informal.

Reference [6] examined a situational context which closely resembles the one investigated in the present study. She looks for indicators of pragmatic awareness in the classroom language of two Finnish teachers teaching an EFL lesson and a "math through the medium of English" lesson. Although her analysis does not focus specifically on directives, these speech acts figure prominently in the study 
since here as in other classrooms teachers simply tend to ask students "to do things in class" [6]. Furthermore, Nikula finds that no matter how large (L1) or small (L2) the modifier repertoire, modifiers are simply not very much in use in these class- rooms. Most of the directives and other teacher utterances in her data are direct and Nikula describes them as "abrupt". In reference to the two different interpretation above, [7] statements may apply in which he says that "tipping the balance in favor of either pragmatic clarity or non-coerciveness will decrease politeness; thus, direct strategies can be perceived as impolite because they indicate a lack of concern with face, and nonconventional indirect strategies (hints) can be perceived as impolite because they indicate a lack of concern for pragmatic clarity." However, [8] asserts that teachers can use very direct expressions of their meaning because of their high status relative to their students. On the other hand, the right and obligations in a role relationship such as teacher-pupil are so clear cut that teachers can also use minimally explicit forms, for example, Blackboard! ('Clean the blackboard'). In fact, a gentle sit down may be far more polite than a thundered I want you all sitting down now. Reference [9] suggests that in respect to language, politeness corresponds to the use of indirect speech acts, addressing others using respectful tone, or utilizing polite utterances such as please, sorry, or thank you. This implies that to judge whether one's directive expressions are polite or not social context such as setting must be taken into account.

This study deals with speech acts in foreign language data, therefore, research on interlanguage pragmatics is considered relevant. All of the studies reviewed appear to suggest that realizations of directives in EFL classroom discourse are likely to be rather limited not only in terms of use but also in terms of the linguistic choices used to encode them. Therefore, the main focus of this paper will be on a description of how directives are actually realized in a sample of senior high school EFL classroom in Indonesia.

\section{METHODOLOGY}

The qualitative study is conducted in senior high school which one of the favorite schools in Kediri, Indonesia where an EFL teacher there is involved. He is chosen because he already has more than ten years experience of teaching English in the senior high school. He also has multi-lingual competence in Javanese, Indonesian, and English so that he can communicate with his students not only in the national and target-language, but also in the mother tongue. It emerges more interaction between the teacher and the students, so the teacher can provide the data for this study.

The data of this research consists of the EFL teacher's directive utterances that are collected through observation (in which recording and note taking were done). The observation is done to help the researcher to find out the directive speech act thoroughly and to see the whole situation of research site and to take notes on important things occurred there. This is in line with [10] who states, "Qualitative observations are those in which the researcher takes field notes on the behavior and activities of individuals at the research site". As a complete observer, her presence at the scene of action does not interact or participate in the activity of the class. This keeps whatever happens in the classroom happens naturally including to make the teacher as the main participant focus on his teaching activity. As such, the study can be categorized as classroom ethnography. The researcher also uses [11] method of transcribing speech orthographically. The transcribing process is done to gain the written document of what the participants in the research site said. The phonetic details of the speaker's accent are omitted, because it is beyond the reach of the study. Therefore, the transcription only consists of the utterances uttered by the participants.

After collecting the data through observation, the data will be transcribed and read closely to find the utterances included to directive speech acts which are used by the EFL teacher. Some steps are carried out for the study, namely as follows: (1) identifying and classifying the utterances which contain directives, such as commands, requests, and suggestions ([1]; (2) analyzing the pedagogical functions of the directives based on the researcher's own interpretation and the teacher speech function categories found by [2]; [12]; [13]; and (3) quantifying the occurrences of the types and functions of directives to see the trend in their use.

In the stage of analyzing the data, the researcher counts the frequency and percentage of each kind of directives performed by the EFL teacher, so it will be known what type of directives mostly used by the participant. Then, the researcher also will count the frequency and percentage of each function of the directives. Finally, the distribution of directive forms and functions will be described and discussed thoroughly.

Further discussion concerns with politeness because it occupies a central place in linguistic pragmatics. To decide which form to use in particular context, social factors which affect a speaker's choice of the appropriate form of directive are suggested to use. The factors including the social distance between the participants, their relative status, and the formality of the context are relevant.

\section{FINDINGS AND DISCUSSION}

To start this section, it is worth revealing that in this research, reference [1] classification was used to describe the types of speech act produced in the English classroom of SMAN 1 Kediri. That is, the speech acts identified was classified into five categories, namely: assertive, directive, commissive, expressive, and declaration.

In terms of frequency of occurrence, the type of speech act that occurred frequently in the classroom was directives $(45.84 \%)$, that was followed by representative (24.00\%), expressive (8.48\%), commissives (1.08\%) and 
declaratives (0,54). From 554 utterances generally the teacher produced more utterances than students did. From the data, the teacher produced 449 utterances $(81.05 \%)$; the students produced 105 utterances $(18.95 \%)$ within the time the observation was done. In reference to this phenomenon it can be inferred that the students learn in teacher centered fashion.

\section{A. The type of directive speech act}

The teacher in SMAN 1 Kediri produced directives speech acts mostly. Reference [1] asserts that the directives speech acts produce an effect through some actions that is done by the hearer. From the data collected, the teachers in SMAN 1 Kediri created this type of speech acts as requestive (ask), requirement (command, order), and advisory (advice, suggest). The requestive type of the teachers' speech acts were used to ask the students about something that were constructed in interrogative form. It applied wh-question, and also yes-no question types. The examples of wh-questions produced by the teacher are: 'maksudnya? (What), whose, which one, which type, how many, how much, and who. Those words can be put at the beginning or at the end of the questions but the teacher seems to always put them at the beginning of their expressions for example 'what are the task?' Meanwhile, in making yes/no question, the teachers chose be, modal auxiliaries and verb treated as auxiliary that were put at the beginning of utterance The examples of yes/no questions used by the teacher are: 'is, am, do, should, auxiliary have, can, and verb have such as 'Instead of using by I think that it's preferable to use in. Is it accepted?'

The requirement (command, order) type of directive speech acts are also greatly produced by the teacher. Orders and commands are speech acts which usually take the form of imperatives while polite attempt to get someone to do something generally use interrogatives or declaratives [8]. Various forms of requirement type found in the data are interrogative with be, interrogative with modal verb can, you imperative (you make a sentence using the word 'denote'), imperative without verb with politeness marker 'please' (okay, next please), declarative (the group of left row answered 'dangerous snake'), declarative with would like formula, and declarative with 'if'.

The advisory type of directive acts is not much used by the teacher. In advisory type the teacher used certain expressions that were intended to give an advice [14] (Searle, 1979). The expressions used were may ('you may find out the meaning in the dictionary...'), and need ('you need to specify four and five').

The existence of command, question and advice in the teaching and learning process develops the role of the teacher as initiator and sustainer of the interaction in the classroom [13]. Appropriate questioning in an interactive classroom can fulfill several different functions. They contribute to the potential learning through their general function in interaction for the core goal which concerns with instructional activities, the framework goal which is mainly for classroom organization and also social goal like disciplining the students as well as for social establishment. In line with [1] assertion, directives are frequent speech acts in classroom interaction it means. As directive requires the learners to perform action it can be argued that with more directive, the classroom interaction becomes engaging.

\section{B. The Functions of the Teacher' Directives and Politeness Strategies}

As frequent speech acts in classroom interaction, reference [1] asserts that directives are used as a command, order, advice, request, etc. Directive speech acts in this study are found to exhibit several certain functions which correspond to pedagogical orientation. In the requestive (question) type they function as asking for confirmation, asking question, elicitation, checking knowledge, checking comprehension, asking for clarification, asking for repetition, and checking learning. Then, in the requirement (command, order) type they function to order the students to do something, calling attention, wishing something to happen, nominating the students, commanding, instructing, grouping, guiding, stimulating, and correcting the students' error. Lastly, the teacher's advisory type of directive has a function as suggestion.

\section{The Function of the Teacher's Directive Speech Acts}

\begin{tabular}{|c|c|c|}
\hline $\begin{array}{l}\text { Directive } \\
\text { types }\end{array}$ & $\begin{array}{l}\text { Pedagogical } \\
\text { Function }\end{array}$ & $\begin{array}{l}\text { Linguistic } \\
\text { samples }\end{array}$ \\
\hline \multirow[t]{8}{*}{$\begin{array}{l}\text { Requestive } \\
\text { (question) }\end{array}$} & $\begin{array}{ll}\text { Asking } & \text { for } \\
\text { confirmation } & \end{array}$ & Very clear, right? \\
\hline & Asking question & Okay, whose thing is it? \\
\hline & Elicitation & Who actually kills the person? \\
\hline & $\begin{array}{l}\text { Checking } \\
\text { knowledge }\end{array}$ & $\begin{array}{l}\text { Everyone, do you see such } \\
\text { kind of mistake in term of } \\
\text { grammar? }\end{array}$ \\
\hline & $\begin{array}{l}\text { Checking } \\
\text { comprehension, }\end{array}$ & So, you've got that? \\
\hline & $\begin{array}{ll}\text { Asking } & \text { for } \\
\text { clarification } & \end{array}$ & $\begin{array}{l}\text { Yes, my further question: } \\
\text { which one is the mistake? }\end{array}$ \\
\hline & $\begin{array}{ll}\text { Asking } & \text { for } \\
\text { repetition } & \end{array}$ & Sorry? \\
\hline & Checking learning & Are you all ready? \\
\hline \multirow{7}{*}{$\begin{array}{l}\text { Requirement } \\
\text { (command) } \\
\text { type }\end{array}$} & Order & Okay, next please. \\
\hline & Calling attention & Hello? \\
\hline & Wishing & $\begin{array}{l}\text { Hoping that you can get the } \\
\text { idea of what is the answer of } \\
\text { the available questions }\end{array}$ \\
\hline & Nominating & Raimond will continue it. \\
\hline & Commanding & Read the rest of the sentences \\
\hline & Instructing & $\begin{array}{l}\text { Yeah, work it together. One } \\
\text { row, one row. }\end{array}$ \\
\hline & Grouping & One row, one row (pointing \\
\hline
\end{tabular}




\begin{tabular}{lll}
\hline Guiding & $\begin{array}{l}\text { each row where the students } \\
\text { are sitting), to find out the } \\
\text { meaning together } \\
\text { Stimulating }\end{array}$ & $\begin{array}{l}\text { Second one. Top right corner? } \\
\text { What do you think of the first } \\
\text { picture? }\end{array}$ \\
& Correcting & $\begin{array}{l}\text { That one is okay, if you'd like } \\
\text { to say that 'the reporter has } \\
\text { exaggerated the news' } \\
\text { becoming active sentence }\end{array}$ \\
$\begin{array}{l}\text { Advisory } \\
\text { (suggestion) } \\
\text { type }\end{array}$ & Suggestion & $\begin{array}{l}\text { You may take any note when } \\
\text { you listen of the every single } \\
\text { information from the audio. }\end{array}$ \\
\hline
\end{tabular}

The data in the table above represent the facts that directive are basically functional in certain context in this case classroom interaction. With its nature as asking someone to do something, the teacher made use of directives for variety of functions which may activate the students to experience more meaningful learning. Obviously, the teacher used a lot questions in issuing the functions of directives. Questions are in fact were used with the highest frequency. The structure of question directives was in interrogative mode which were used not only to control and manage the classroom but also for instructional purpose. For example; what do you infer from the picture...? Giving question was a good way to involve the students in the teaching and learning process in which two ways of interactions can be formed. However, the teacher was the dominant one in making question, while the students mostly respond the teacher's question in a declarative form and made only occasional questions like asking for confirmation to the teacher for their prediction such as the following example:

\section{T: OK, what is it? I don't think this is a python. S: A snake?}

Generally, question directives are categorized as polite expressions. However, bald imperatives also appear quite a lot in classroom interaction. They were used mainly to ask the students to do something nonverbally. Anyhow, it does not mean that the teacher was rude or impolite. Considering the relative status of teacher and students, imperative is appropriate to be uttered by the superior. Beside that as long as they are nicely expressed, this kind of speech acts do not cause any threat on the part of the students. Another politeness indicator performed by the teacher is the use of marker 'please' such as in 'Okay, next please'. When issuing orders, the word 'try' can also become a sign of being polite and this word was practiced frequently as well. Declarative forms of directive also occur as can be seen in nominating the student, 'Raimond will continue it'. Thus, it can be concluded that the teacher did perform directives in appropriate way.

\section{CONCLUSION}

The author has discussed about the frequency, type, and function of directive speech acts produced by the English teacher in SMAN 1 Kediri, Indonesia. From the analysis of the teachers directive speech acts produced during the teaching and learning process in second grade at SMAN 1 Kediri, this research comes to some conclusions as follow.

First, the teacher produced more utterances than students for pedagogical purposes including social and instructional. The frequency of the teachers' directive speech acts implied that the degree of the asymetricality in conducting the teaching and learning was high. However, this was considered appropriate since the intention was to benefit the students. Authority role of teacher indicated the vertical status difference in the classroom. Producing more utterances in classroom interaction, the teacher was also more dominant in directive uses other than the students. With the roles and responsibility the teacher has, it is common if he asks the students to do the orders for example asking the students to say a sentence, to answer questions, and to follow the teachers' instruction as common orders from teachers. The expectation of the teacher in using directives in the classroom is the students' compliance.

Directives are used in the form of interrogative, imperatives, and declaratives for various functions that are typical in classroom discourse. The functions of the teachers' directive speech acts at SMAN 1 Kediri are mostly instructional and managerial functions. These include for examples; instructional: asking for confirmation, asking question, elicitation, checking knowledge, checking comprehension, asking for clarification, asking for repetition; managerial: checking learning, ordering the students to do something, calling attention, wishing something to happen, nominating the students, commanding, instructing, grouping, guiding, stimulating, and correcting the students' error and lastly, suggestion.

In his directive performance, the teacher is considered polite in term of [13] view. This is indicated by more questions used, gentle imperatives, declarative expressions, the marker 'please' and also the lexical use of 'try'. This means that the classroom interaction in SMAN 1 Kediri has taken place to be teacher fronted in which the students mostly learn from the teacher's appropriate directive speech acts.

Thus, it can be concluded that the directive speech act is a powerful type of act in teacher fronted classroom discourse because of its high frequency of use, interactional functions which involve all interactional goals, and grammatical forms in which depending on the way they are expressed and the social factors in which they are used, even imperatives (direct commands) can be polite.

This study has some limitations especially in the amount of data, the number of participant, and the depth of 
analysis. Therefore, this research result cannot be generalized. However, this can be a starting point or a basis for further research. Further researchers are, then, suggested to conduct similar study with more data, participants, and also with deeper analysis in order to credibly contribute to the development of the knowledge of applied pragmatics.

\section{REFERENCES}

[1] J. Searle, Speech acts: An essay in the philosophy of language. Cambridge, Cambridge University Press, 1969.

[2] R. Ellis, "Learning to communicate in the classroom: a study of two learners' requests," Studies in Second language Acquisition, vol. 14, 1992, pp.1-23.

[3] C. Dalton-Puffer, "Telling each other to do things in class: directives in content and language integrated classrooms," Views, vol. 12, 2003, pp. 3-23.

[4] N. Ainani Fitria, "The analyses of classroom speech acts produced in the teaching and learning of English as a foreign language, " unpublished thesis.

[5] C. Falsgraf and D. Majors, "Implicit culture in Japanese immersion classroom discourse," Journal of the Association of Teachers of Japanese, vol. 29, 1995, pp. 1-21.

[6] T. Nikula, Teacher talk reflecting pragmatic awareness: a look at EFL and content-based classrooms. Pragmatics, vol. 12, 2002, pp. 447467

[7] S. Blum-Kulka, "Indirectness and politeness in requests: Same or different?," Journal of Pragmatics, vol.11, 1987, pp.131-146.

[8] J. Holmes, An Introduction to Sociolinguistics. London: Longman, 1992.

[9] R. J. Watts, Politeness, Cambridge: Cambridge University Press, 2003.

[10] J.W. Creswell, Research design: Qualitative, quantitative, and mixed methods approaches, 3rd ed, Thousand Oaks, California: Sage Publications, Inc., 2009.

[11] A. Wray, K. Trott Bloomer, A. Projects in linguistics. New York: Oxford University Press, 1998

[12] M. Stubbs, Discourse Analysis: The Sociolinguistic analysis of natural language, Chicago: The University of Chicago Press, 1983.

[13] H. Douglas Brown, Teaching by principles: An interactive approach to language pedagogy, 2nd ed, White Plains, NY: Longman, 2001.

[14] .J. Searle, Expression and Meaning: Studies in the Theory of Speech Acts, Oxford: Oxford University Press, 1979. 